DOI: 10.20472/IAC.2017.33.070

\author{
GÜNEŞ TOPÇU \\ Çanakkale Onsekiz Mart University, Turkey \\ AHMET BURAK EMEL \\ Tekfen Holding, Turkey \\ TUĞÇE ÖZBEY GÜRKAN \\ Vakıfbank, Turkey
}

\title{
EARLY WARNING MODELING FOR FINANCIAL FAILURE: BORSA ISTANBUL CASE
}

\begin{abstract}
:
This study aims at financial failure prediction. The data consist of financial ratios and bankrupt information of the randomly selected 39 real sector companies listed in Borsa İstanbul over the period 2012 to 2014 and 15 real sector companies for the following year, i.e. 2015. As real-life bankruptcy is rarely observed for publicly traded companies, a proxy is used for failure behavior. The proxy used is "being transferred to Watchlist Companies Market of Borsa İstanbul (BIST)". Multiple discriminant analysis (MDA) was used in analyzing data. To validate identification ability of the MDA model, 4 scenarios are created. To assess the prediction ability of the MDA model, z-scores of the companies are calculated for the year 2015. The discriminant function achieved a $100 \%$ classification success for the model data and $73.3 \%$ for the forthcoming year failure behavior prediction.
\end{abstract}

\section{Keywords:}

Bankruptcy prediction, Borsa İstanbul, watchlist market, MDA, credit risk, Altman's z-score

JEL Classification: C51, G17, G33 